\section{Pavilhão Mourisco no contexto do ecletismo carioca}

\section{The Moorish Pavilion in the context of eclecticism in Rio de Janeiro}

\section{Renato da Gama-Rosa Costa}

'Coordenador e professor, Programa de Pós-graduação Stricto sensu em Preservação e Gestão do Patrimônio Cultural das Ciências e da Saúde, Casa de Oswaldo Cruz/Fiocruz. Rio de Janeiro - RJ - Brasil

orcid.org/0000.0002.2569.0912

renato.gamarosa@fiocruz.br

\section{Inês El-Jaick Andrade $e^{i i}$}

ii Professora, Programa de Pós-graduação Stricto sensu em Preservação e Gestão do Patrimônio Cultural das Ciências e da Saúde, Casa de Oswaldo Cruz/Fiocruz. Rio de Janeiro - RJ - Brasil

orcid.org/0000-0001-9012-6421

ines.andrade@fiocruz.br

Recebido em 30 ago. 2019.

Aprovado em 8 jan. 2020.
COSTA, Renato da Gama-Rosa; ANDRADE, Inês El-Jaick. Pavilhão Mourisco no contexto do ecletismo carioca. História, Ciências, Saúde Manguinhos, Rio de Janeiro, v.27, n.2, abr.-jun. 2020, p.543-563.

Resumo

$\mathrm{O}$ artigo conta a história do projeto do Pavilhão Mourisco, edifício-sede da Fundação Oswaldo Cruz, no Rio de Janeiro, suas influências e construção. Terminado em fins de 1918, celebrará, em 2021, 40 anos de sua preservação pelo Instituto do Patrimônio Histórico Nacional, como uma das construções mais representativas do período eclético da arquitetura brasileira. Projetado pelo português Luiz Moraes Jr., sua configuração recebeu influências estéticas, formais, espaciais e funcionais das mais diferentes origens, o que consolidou seu reconhecimento oficial como patrimônio cultural brasileiro. $\mathrm{O}$ texto também analisa o contexto urbano em que se deu sua implantação na cidade do Rio de Janeiro e ressalta o momento de revisão historiográfica da arquitetura que contribuiu para o processo de seu reconhecimento enquanto valor cultural e científico.

Palavras-chave: arquitetura eclética; Pavilhão Mourisco; Patrimônio da Ciência e da Saúde.

\section{Abstract}

The article tells the history of the design of the Moorish Pavilion, headquarters of Fundação Oswaldo Cruz (Fiocruz), completed in 1918. The year 2021 marks the fortieth anniversary since its listing by the Brazilian heritage protection agency, Instituto do Patrimônio Histórico Nacional, as one of the most representative examples of eclectic architecture in Brazil. Designed by the Portuguese architect Luiz Moraes Jr., its aesthetic, formal, spatial, and functional features derive from multiple influences, which consolidated its recognition as Brazilian cultural heritage. The urban setting in which it was built, in Rio de Janeiro, is also analyzed, and the revision of the historiography of Brazilian architecture, instrumental in the recognition of its cultural and scientific value, is appraised.

Keywords: eclectic architecture; Moorish Pavilion; health and science heritage. 
A Fundação Oswaldo Cruz é originária do antigo Instituto Soroterápico de Manguinhos (1900), que depois se tornaria Instituto de Patologia Experimental (1907), Instituto Oswaldo Cruz (1909), Fundação Recursos Humanos para a Saúde (1969) e, finalmente, Fundação Instituto Oswaldo Cruz (Fiocruz), em 1970 (Costa, 15 maio 2018). Foi instalada em terrenos de uma antiga fazenda, situada às margens da baía de Guanabara, na região de Manguinhos, desapropriada pelo governo federal em 1892 (Benchimol, 1990).

Ali surgiria uma das maiores instituições de pesquisa em saúde da América Latina. A história de seu desenvolvimento se confunde com a própria história da cidade do Rio de Janeiro, que, nos primeiros anos do século XX, passaria por uma urbanização expressiva. Aliado a todo esse crescimento, tendo Pereira Passos, entre 1902 e 1906, à frente da prefeitura da então capital federal, vemos a consolidação da arquitetura eclética em nossa cidade (Benchimol, 1990), em que tecnologias contemporâneas, como eletricidade, gás encanado, sistemas de distribuição de esgoto e de água limpa, e o uso de materiais como ferro, cimento e vidro, conviveriam com estilos do passado que deram origem a novas nomenclaturas, como o neogótico, o neogrego, o neoárabe, ou mesmo o neomourisco, que seria usado como linguagem arquitetônica no principal edifício do Instituto Oswaldo Cruz. Este artigo conta a história de seu projeto, influências e construção, bem como analisa o contexto urbano em que se deu sua implantação na cidade do Rio de Janeiro. Conclui-se o estudo discorrendo sobre a mudança de mentalidade no campo do patrimônio que contribuiu para o processo de reconhecimento do Pavilhão Mourisco como valor cultural e científico.

Para Claude Mignot (1983), os anos entre 1840 e 1850 foram os mais controversos na história da arquitetura europeia, período comumente conhecido por "eclético", iniciado pelo revivalismo do gótico e da tradição greco-romana:

Os arquitetos tinham consenso em condenar o pastiche, mas todos apoiavam a ideia de que não era uma questão de imitação do passado e, sim, unicamente uma forma de buscar inspiração em seus princípios e experiência, com o intuito de vislumbrar o estilo do século XIX; todos praticavam a citação, o prazer que recentemente se derivava de um desenvolvimento da estética pitoresca (Mignot, 1983, p.100). ${ }^{1}$

O modo de projetar dos arquitetos do eclético adotava ora um princípio estrutural, ora uma forma arquetípica, às vezes um lay-out, um motivo, e os adaptava para seus recursos e necessidades dos tempos modernos (Mignot, 1983). Mas essa diversidade, continua o autor, contava, também, com a participação dos clientes dos arquitetos. Tanto para um quanto para outro, o código usado pelo ecletismo era facilmente compreensível à época: "A desconcertante justaposição de diversos estilos era um dos meios de expressão disponível aos arquitetos" (p.100).

Segundo Mignot (1983), o termo "ecletismo" englobava dois fenômenos diferentes: o tipológico e o sintético. Em ambos os casos, a filiação a um ou outro fenômeno dependia das intenções do arquiteto e, não menos importante, de seu cliente. No tipológico, adotavase apenas um único modelo estético do passado, adaptando-o às necessidades do projeto, qualquer que fosse ele. Já no sintético, o arquiteto se via à vontade para escolher diferentes modelos do passado, em seus princípios, soluções e motivos que, combinados, davam a estética final do projeto. 
Na perspectiva de Luciano Pateta (1987), vinculada ao movimento de revisão historiográfica do ecletismo europeu da segunda metade do século XX, todavia, uma série de fenômenos unia os fragmentos históricos: a consolidação do poder burguês, os rumos tomados pela civilização industrial, o entrelaçamento das ideias nacionais e de independência, entre outros. Como consequência, considera que o período que se estende da metade do século XVIII até o início do XX corresponde a um "único e longo período" que guarda uma continuidade histórica da arquitetura burguesa, a qual se convencionou denominar "ecletismo". O autor destaca que o ecletismo era a cultura arquitetônica própria de uma classe burguesa em ascensão que buscava conforto e "amava o progresso (especialmente quando melhorava suas condições de vida), amava as novidades, mas rebaixava a produção artística e arquitetônica ao nível da moda e do gosto" (Pateta, 1987, p.13). Seguindo a mesma premissa, o autor afirma que o historicismo arquitetônico e o urbanismo do século XIX desenvolveram-se na "mais perfeita simbiose" (p.23).

Em sua análise, Pateta (1987) considera pelo menos três correntes principais na produção arquitetônica eclética: a da composição estilística (tendências dos revivals), a do historicismo tipológico (orientada por modelos analógicos calcados na finalidade proposta) e a dos pastiches compositivos (invenção de soluções estilísticas historicamente inadmissíveis). $\mathrm{O}$ autor adverte que, em todas essas correntes, mesmo baseados no mais apurado levantamento na busca por replicar o monumento antigo, os resultados produzidos pelos arquitetos historicistas foram simulacros da realidade, visto que, ao retificar e corrigir presumíveis erros dos originais, criava-se algo novo - o estilo próprio de seu tempo.

Sendo assim, podia-se ver referências a diferentes e diversos modelos do passado, entre linguagens greco-romanas, góticas, bizantinas, barrocas e árabes, indicando na maioria das vezes uma associação entre estilo e função, dentro do que se pode considerar architecture parlante. $^{2}$ Este último estilo, por exemplo, era apropriado para edifícios recreativos: "De modo inverso, o mesmo estilo pode aparecer em diferentes edifícios por conta de diferentes associações mentais. Por exemplo, o mesmo estilo de inspiração oriental pode ser encontrado em uma sinagoga, como a de Berlim (1859), ou em uma excêntrica residência, ... em Lille (1892), ambas em estilo mourisco" (Mignot, 1983, p.107).

A celebração dessa cultura arquitetônica pode ser representada nas estruturas imponentes dos pavilhões, sobretudo os nacionais, das exposições universais (Londres 1851 e 1862; Paris 1867 e 1889; Viena 1873; Filadélfia 1876; Chicago 1893; Saint-Louis 1904; Liège 1905; Milão 1906; Bruxelas 1910; e Grand 1913). A representação internacional era significativa, abrangendo desde países europeus e os EUA até regiões sob pleno regime colonial imperialista. Os eventos tinham uma esporadicidade regular e recebiam forte cobertura pela imprensa. Outros autores já destacaram que essas feiras eram eventos de grande porte que extrapolavam sua finalidade de ser uma vitrina de progresso e indústria dirigida para o comércio de novidades e divulgação de avanços das atividades manufatureiras e industriais, mas eram a representação material do projeto capitalista de mundo concebido pela filosofia dominante (Barbuy, 1996; Pereira, 2013). E, dentro desse contexto, a linguagem arquitetônica eclética valeu-se da abrangência das feiras para encontrar o "tom exato de autocelebração" na arquitetura de seus pavilhões (Pateta, 1987, p.13). Para Pereira (2013), essas grandes feiras representaram um dos mais importantes espaços educativos da cultura 
do século XIX, pois eram voltadas para o público em geral citadino e apresentavam outras cidades, povos e culturas de uma maneira hierarquizada a partir de uma visão única e evolucionista de desenvolvimento e história. Essa nova prática social do exercício de olhar, comparar e julgar era exemplificado pela aparência dos pavilhões exóticos.

Através da linguagem estilística adotada em cada contexto e país - greco-romana; gótica, mourisca, turca... - ou do desenvolvimento tecnológico exibido, julgava-se o seu nível de civilidade, cosmopolitismo e progresso. Na verdade, pode-se dizer que a ideia de Exposição Universal e sobretudo esse julgamento comparativo de povos e culturas veio consolidar novas práticas sociais e um novo trinômio: exibir, admirar e consumir (Pereira, 2013, p.8-11).

Cabe destacar que o Brasil começou a participar com uma delegação de empresários e jornalistas das exposições apenas a partir da Exposição de Filadélfia, em 1876. Contudo, as feiras começam a receber as primeiras seções nacionais em 1867, incluída a edificação de diversos pavilhões seguindo correntes do orientalismo (Vasseur, 2001), mas somente em 1876 a construção de pavilhões nacionais se torna uma prática consolidada (Barbuy, 1996).

\section{O Rio civiliza-se! A construção de uma nova cultura urbana e arquitetônica}

$\mathrm{Na}$ Europa, no final do século XIX e início do XX, consolidava-se a política de higiene pública entendida como a técnica de controle para garantir a salubridade do espaço urbano, isto é, a base material e social capaz de assegurar a melhor saúde aos indivíduos. Os médicos, fundamentados em teorias que localizavam a doença no meio ambiente, elaboraram um discurso que se propunha a medicalizar o espaço e a sociedade, influenciando, dessa maneira, as práticas sociais e as políticas urbanas.

De fato, os médicos, juntamente com engenheiros e arquitetos, exerceram um papel crucial no planejamento urbano e no campo de saberes sobre a cidade. As intervenções urbanas passaram a seguir critérios de organização, salubridade, funcionalidade, mas também critérios de embelezamento urbano. É, portanto, possível afirmar que o princípio da ideia de saneamento urbano atual começa a se construir a partir dos fins do século XVIII com o movimento higienista francês: "No século XIX, o nascimento de um movimento a favor do urbanismo está diretamente ligado a uma sensibilidade generalizada para as questões de higiene pública" (Calabi, 2012, p.81).

Dessa forma, passaram a ser analisados e combatidos na malha urbana os acúmulos que poderiam gerar confusão, perigo e doenças no espaço urbano, controlada a circulação de água e ar para evitar contaminações e organizadas a distribuição e sequências de água e esgoto para evitar contaminação. Essas medidas profiláticas sobre as epidemias eram orientadas pela teoria miasmática.

No Rio de Janeiro, entre 1903 e 1906, ocorreram profundas transformações no espaço da capital da República realizadas pelo Ministério de Viação e Obras Públicas e pela Prefeitura do Distrito Federal. A cidade foi alvo principal das intervenções de caráter de embelezamento, sobretudo no Centro da cidade (Benchimol, 1992). Estas deram sequência a uma série de outras, que também ostentavam como bandeira a higienização da capital 
e a modernização do porto da cidade. Segundo Pereira (2013, p.14), essas transformações marcaram novos tempos na história do país, uma vez que a imagem percebida era "como se o Brasil inteiro subitamente houvesse modernizado o conjunto de suas instituições e a própria mentalidade e os hábitos dos seus habitantes".

Para Nicolau Sevcenko, no final do século XIX e início do XX, um fluxo intenso de mudanças atingiria todos os níveis da experiência social:

Nunca em nenhum período anterior, tantas pessoas foram envolvidas de modo tão completo e tão rápido num processo dramático de transformação de seus hábitos cotidianos, suas convicções, seus modos de percepção e até seus reflexos instintivos. Isso não apenas no Brasil, mas no mundo tomado agora como um todo integrado (Sevcenko, 1998, p.8).

Contribuindo para a construção da nova imagem da capital brasileira, estava em andamento uma progressiva mudança de mentalidade sanitária, responsável pelo controle das epidemias que ceifavam vidas no século XIX e conferiam ao país a nada honrosa reputação de "túmulo dos estrangeiros". A primeira grande epidemia de febre amarela na cidade do Rio de Janeiro ocorreu em 1849 e foi o que levou o governo imperial a aprovar, em 1850, a crição da Junta de Higiene Pública, com a finalidade de inspecionar todos os lugares de onde poderiam ser gerados danos à saúde pública. Sua criação é representativa, pois é considerado o momento em que instâncias médicas assumiam o controle das medidas de higiene pública. Entre suas atribuições estava a inspeção da vacinação, o controle do exercício da medicina e a polícia sanitária da terra, que englobava a inspeção de alimentos, farmácias, armazéns de mantimentos, restaurantes, açougues, colégios, cadeias, aquedutos, cemitérios, oficinas, laboratórios, fabricas e, inclusive, hospitais (Benchimol, 1992).

Já no período republicano, em 1897, os serviços relacionados com a saúde pública passaram a integrar a Diretoria Geral de Saúde Pública, vinculada ao Ministério da Justiça e Negócios Interiores. A partir de 1903, o médico sanitarista Oswaldo Gonçalves Cruz (18721917) é nomeado diretor-geral de Saúde Pública e passa a atuar ativamente na luta para combater a febre amarela na cidade. Cruz estava, então, vinculado ao movimento sanitário brasileiro. Os principais argumentos utilizados na reforma de melhoramento da capital do Brasil da Primeira República, durante a gestão do prefeito Pereira Passos, foram readequar o espaço urbano às exigências de uma nova realidade econômica: o desenvolvimento industrial (Benchimol, 1990). Porém, a estética urbana acaba tornando-se o elemento central no projeto republicano de inserção do país no dito mundo civilizado e na competição com outras capitais da América Latina (Buenos Aires e Montevidéu), reduzindo o impacto no campo do saneamento (Pinheiro, 2002).

Assim, intervenções pontuais foram o ponto de partida para se alcançar uma imagem que o país desejava, em vez de executar mudanças estruturais que, em outros países, caracterizava o processo de modernização urbana. Na visão desse modelo civilizador, o traçado da cidade com feitios coloniais - ruas estreitas, calçamento irregular, esgotamento a céu aberto, casario rasteiro e iluminação feita por lampadários - daria lugar a uma civitas moderna e cosmopolita para as elites (Abreu, 1987). 
Nas cidades de grande ou médio porte, as residências e os prédios públicos receberam ornamentos de repertórios variados, da segunda metade do século XIX até as primeiras décadas do século XX. Nesse contexto, a linguagem eclética foi aplicada no Brasil para compor o repertório formal instituído pelo plano de remodelação da capital, que utilizava o modelo urbano francês difundido e adaptado à capital republicana.

A arquitetura eclética surgida na Europa adotava uma linguagem historicista e tradicionalista na sua aplicação, ao mesmo tempo que dispunha de materiais e técnicas provenientes da industrialização, geralmente utilizados nas instalações e na infraestrutura dos edifícios. Da mesma forma, no Brasil, as inovações técnicas construtivas das edificações ecléticas estão relacionadas, de um modo geral, ao emprego de novos materiais importados e, também, às soluções de infraestrutura, como sistemas elétricos, hidráulicos, sanitários, de comunicação, entre outros. No nosso caso, em particular, foram dados incentivos fiscais para a importação de materiais de construção industriais e a introdução de novas tecnologias, que, associados ao trabalho especializado no campo da construção civil, permitiram a substituição, ao longo dos anos que se seguiram, das usuais estruturas mistas para estruturas em concreto armado, por exemplo.

O estilo então em voga adotava fachadas e interiores que remetiam a um passado histórico, fosse clássico, egípcio ou mesmo a união de vários, como nos aponta Mignot. Já na metade do século XX, este é objeto de violenta crítica e combate de arquitetos modernos, por ser considerado um estilo desprovido de qualidades arquitetônicas e falsificação histórica, a negar sua temporalidade. No auge do modernismo, o ecletismo passaria a ser objeto de pesadas críticas de eruditos.

O Pavilhão Mourisco, edifício-sede da Fundação Oswaldo Cruz (Fiocruz), pode ser valorizado tanto por suas qualidades arquitetônicas quanto por pertencer a um conjunto arquitetônico expressivo de inícios do século XX, de relevante inovação tecnológica a serviço da saúde à época e de destaque na paisagem cultural do Rio de Janeiro ainda hoje. Sua análise, para este artigo, privilegia as influências diversas conferidas ao projeto até sua feição final, revelando os interesses do seu autor, o arquiteto Luiz Moraes Jr., mas, sobretudo, de seu cliente, o cientista Oswaldo Cruz, e cujo enredo pode parecer de fato confuso, mas não menos estimulante.

Começamos pelos relatos compilados por Fonseca Filho, em 1972, que testemunham o que dissemos. Alguns justificavam uma possível influência da linguagem utilizada simplesmente pela ascendência árabe do arquiteto, explicando, de certa forma, a aplicação de "tão inusual estilo para uma casa de ciência" (Fonseca Filho, 2000, p.103). Outra versão citada seria a opção de Oswaldo Cruz "pela necessidade de chamar a atenção do público leigo, dando à sua sede uma aparência espetacular" (p.104). Entre as opiniões sobre as motivações da escolha do estilo mourisco para o edifício-sede do então Instituto Oswaldo Cruz, está a de Pedro Bloch, que, segundo Fonseca Filho, melhor resumiu à época a sensação que se apoderava de quem se confrontava com a monumental edificação: "Visão que agride a paisagem. Um enorme palácio mourisco. Que tem aquilo a ver com o resto da cidade? Que incoerência fez aquele berro arquitetônico fugido de alguma capital do oriente? Aquilo é o Instituto Oswaldo Cruz, de gloriosa história, centro científico respeitado e honrado em todos os cantos da terra" (p.104). 
A realização do projeto procurou responder não apenas às preferências estilísticas de seus idealizadores, mas, igualmente, ao exigente e inédito programa de uso da edificação para o Brasil à época: sede administrativa e laboratorial de um instituto de pesquisa, produção e ensino em saúde, o que demandava soluções ainda pouco encontradas nas edificações de então, como veremos.

\section{O Instituto em Manguinhos}

Em fins de 1899, o barão de Pedro Affonso (1845-1920), diretor do Instituto Vacínico Municipal, que funcionava na região do Catete, havia proposto ao então prefeito do Rio de Janeiro, Cesário Alvim (1839-1903), a instalação de um laboratório soroterápico na Fazenda Municipal de Manguinhos, com o objetivo de preparar soro antipestoso em grande escala (Benchimol, 1990; Costa, 15 maio 2018). Com o ofício n.490, de 25 de maio de 1900, "ficavam autorizadas as obras de conclusão do instituto e, também, a transferência das instalações, então adaptadas pelo barão na Fazenda de Manguinhos, da alçada municipal para a responsabilidade federal. Nascia, assim, o Instituto Soroterápico Federal" (Costa, 15 maio 2018, p.1).

A escolha de tal terreno deveu-se à sua localização em uma área afastada do Centro do Rio de Janeiro, situada entre os bairros de Benfica e Bonsucesso, e o porto de Inhaúma. O barão de Pedro Affonso, em depoimento ao Jornal do Commercio de 26 de fevereiro de 1915, afirmava que, depois de percorrer "grande número de ilhas da nossa baía", pensou em instalar o instituto junto ao laboratório militar da Quinta da Boavista, mas, decide pelo terreno em Manguinhos, uma antiga fazenda de propriedade de Alexandrina Rosa de Carvalho, já desapropriada desde 1892 por decreto federal, para ali serem construídos fornos de incineração de lixo da cidade do Rio. As primeiras instalações do instituto criado pelo barão foram oficialmente inauguradas em 23 de julho de 1900, utilizando salas adaptadas das antigas casas da fazenda, ou seja, espaços acanhados e de funcionalidade limitada, que seriam, depois, transformados por Oswaldo Cruz:

Recém-chegado de Paris, onde havia aprimorado sua formação no Instituto Pasteur, o médico Oswaldo Cruz seria um dos primeiros a trabalhar no instituto comando pelo barão. Com a exoneração a pedidos do próprio Pedro Affonso, em dezembro de 1902, Oswaldo Cruz assumiria a direção do instituto com a missão de prosseguir com a fabricação de soros e vacinas e atacar as epidemias de peste, febre amarela e varíola que ameaçavam a então Capital Federal (Costa, 15 maio 2018, p.2).

O médico sanitarista Oswaldo Gonçalves Cruz, formado pela Faculdade de Medicina do Rio de Janeiro, em 1892, e atuando na Policlínica Geral do Rio de Janeiro desde 1894, embarcou para Paris (França) a fim de se especializar em microbiologia e soroterapia no Instituto Pasteur, em abril de 1897. Permaneceu dois anos e três meses no solo francês. Além de ingressar como bolsista do Instituto Pasteur, epicentro das pesquisas em microbiologia de então, também estudou no Laboratório de Toxicologia, aprendendo medicina legal, e iniciou sua atividade de fotógrafo amador, "paixão que alimentaria pelo resto da vida" (Klein, 2003, p.11). 
Em sua estada na França, teve a oportunidade de vivenciar espaços livres modelados ao gosto romântico (parques urbanos públicos e avenidas arborizadas), conjuntos arquitetônicos de novos bairros e a nova imagem de uma Paris produzida pelas transformações urbanas, naquele que se tornou o modelo mais difundido e adaptado em outras cidades pelo mundo: a reforma urbana de Paris do segundo Império (1852-1870). Entre 1853 e 1870, o barão Georges-Eugène Haussmann foi prefeito de Paris e ali realizou inúmeras intervenções que resultaram em significativas transformações para a cidade, ${ }^{3}$ já considerada importante centro mundial de cultura e civilização. Para este estudo, consideramos importante a vivência de Oswaldo Cruz nas instalações do observatório de Montsouris, então localizado na capital francesa, para a concepção da composição estilística do Pavilhão Mourisco.

Fonseca Filho (2000) destaca o tempo que o médico permaneceu em Paris e que, apesar do reconhecimento da forte influência de Montsouris no projeto final do Castelo de Manguinhos, chama a atenção para ausência de referências a Pierre Miquel (1850-1922) nos escritos do cientista à época da elaboração de sua tese de doutoramento. Segundo Fonseca Filho, Miquel era a maior autoridade francesa sobre microbiologia da época, estando, então, à frente do serviço de microbiologia do Observatório Meteorológico de Montsouris, implantado em um parque urbano de mesmo nome:

o Instituto tomou evidentemente por modelo, praticamente fazendo copiar-lhe todos os pormenores arquitetônicos, o edifício daquele observatório parisiense. O estilo, no sentido próprio, exótico, do prédio central de Manguinhos, tem, sem dúvida, alguma desta origem, sendo fantasiosas as explicações que se tem dado de sua escolha, pela influência que, sobre a imaginação ao mesmo tempo criadora e sonhadora de Oswaldo Cruz, teria tido a arte de Granada mourisca, ou ainda, de um imaginado influxo ancestral que se teria exercido sobre o distinto arquiteto português Luís de Moraes, que traçou os planos e dirigiu as obras de construção do edifício central (Fonseca Filho, 2000, p.103).

Ainda durante sua estada em Paris, Oswaldo Cruz visitou, no dia 24 de julho de 1898, a seção do Instituto Pasteur instalada em Garches, "pequena cidade localizada a 9 quilômetros a N.E. de Versalhes" (Cruz, 1972, p.285; originalmente publicado em 1898). Lá, teve contato com instalações que, de certa forma, teriam muitas semelhanças com o que ele conheceria ou mesmo proporia para Manguinhos:

No meio de um terreno plano, eleva-se o Instituto soroterápico d'entre extensos tapetes de verdura, que servem de pastagem aos cavalos destinados à produção dos soros. Transpondo-se o portão de zinco, que dá acesso à propriedade, divisa-se ao fundo a floresta de St. Cloud; à esquerda, a via férrea; à direita, sobre uma eminência, as ruínas d'um antigo castelo (Cruz, 1972, p.285).

Essas impressões sobre sua visita a Garches certamente ressurgiram quando, a convite do barão, Oswaldo Cruz foi trabalhar em Manguinhos. As instalações visitadas, a saber, a "cocheira destinada aos cavalos que estão em via de imunização contra o tétano, a streptcoccia e a peste ... as estrebarias dos cavalos produtores do soro antidiftérico" (Cruz, 1972, p.286), além de enfermarias para tais animais e o viveiro de cobaias, fartamente descritas por Oswaldo Cruz em seu relato para a revista Brasil Médico, invariavelmente devem 
ter sido responsáveis por contribuir nas escolhas acerca de como concretizar a instalação do que viria a ser o seu próprio instituto, uma década depois. Será que o tal castelo em ruínas teria inspirado o cientista brasileiro a fazer o seu, depois da saída do barão? Uma dúvida que torna a história de Manguinhos ainda mais fascinante.

Nesse mesmo relato, é possível encontrar descrição acerca de salas espaçosas e ventiladas, "construídas com todos os preceitos de higiene moderna"; de formas construtivas, como "arestas vivas dos ângulos formados pelo encontro das paredes, [que] são arredondados" (Cruz, 1972, p.286); além de materiais utilizados nas construções, como azulejos, cimento, entre outros, tudo que se pode encontrar em Manguinhos. Ao final do relato, Oswaldo Cruz menciona um "santuário" preparado após a morte de Pasteur: um modesto quarto localizado no andar superior do edifício principal, que guardava as lembranças do que havia sido um aposento do cientista francês, com sua cama, sua mesa de trabalho e "grinaldas, palmas e placas comemorativas vindas por ocasião dos funerais, de quase todos os países do mundo" (p.305-306). Aqui, Oswaldo Cruz anteviu a criação de seu próprio "santuário", para as homenagens que a ele seriam destinadas, após sua morte, em seu castelo.

Com essas imagens na cabeça, faltava a Oswaldo Cruz encontrar quem as concretizasse, e isso se daria de forma fortuita. Moraes Jr. trabalhava nas obras de reforma da igreja da Penha por convite feito pelo vigário-geral daquela paróquia, o padre Ricardo. As obras durariam de 1900 a 1902, mesmo período de funcionamento das primitivas instalações adaptadas pelo barão nas casas da antiga fazenda de Manguinhos:

Oswaldo Cruz certamente acompanhou com admiração o serviço elaborado por Moraes na igreja da Penha, durante a convivência de ambos no trajeto do trem no ramal da Leopoldina, que pegavam para se deslocarem cada um para seus respectivos trabalhos. O cientista teria feito o convite para projetar os novos laboratórios, talvez descontente com os recursos que eram oferecidos pelo barão. Oswaldo Cruz, com a saída de Pedro Affonso, pôde, finalmente, convidar oficialmente Moraes a projetar as novas instalações dos laboratórios, com o desejo de os tornar os mais avançados à época (Costa, 15 maio 2018, p.3).

Moraes Jr. estava recém-chegado de Coimbra, Portugal, tendo se graduado em engenharia ferroviária, em Lisboa. Sua atuação na igreja vizinha abriria as portas de Manguinhos ao português e, depois, para a própria área da saúde. Não temos registro das atividades do engenheiro-arquiteto Moraes Jr. antes de sua chegada ao Brasil, mas é possível supor que, na idade de 31 anos, ele já tivesse uma produção arquitetônica significativa em Portugal.

As origens do arquiteto ainda suscitam debates. No livro Manguinhos do sonho à vida, de Jaime Benchimol, o nascimento de Luiz de Moraes Jr., com informações baseadas em um obituário lançado em 1955, ano de seu falecimento, está registrado como tendo ocorrido em 28 de janeiro de 1868. Entretanto, pesquisas recentes nos arquivos da cidade de Faro (Faro..., 1867, entrada n.18), revelaram outra data para o seu nascimento e outra grafia para seu nome:

Aos vinte e cinco dias do mês de fevereiro do ano de mil oitocentos e sessenta e sete, nesta Igreja paroquial de S. Pedro, conselho de Faro, diocese do Algarve, batizei solenemente um indivíduo do sexo masculino, a quem dei o nome de Luiz, e que nasceu nesta freguesia às sete horas da noite do dia trinta do mês de janeiro do ano de 
mil oitocentos e sessenta e sete, filho legítimo de Luiz Moraes, fundidor, natural da Freguesia de Jesus, em Lisboa, e de Eugênia Emília da Fonseca, natural da Freguesia de São Pedro d'Alcântara, em Lisboa, recebidos nesta Freguesia Matriz de Faro, paroquianos da mesma, moradores da Rua da Cruz das Mestras; neto paterno de avós incógnitos, e maternos de António da Fonseca e Matilde Rosa (Livro..., 1867, entrada n.18).

Alguns documentos pertencentes ao Fundo Luiz de Moraes Jr. (DAD/Fiocruz) apresentam a forma "de" Moraes. Entretanto, em documento de sua autoria em que relata brevemente seu currículo, em francês, ele se nomeia Luiz Moraes Jr. (DAD/Fiocruz). Da mesma forma, na pedra colocada à fachada principal do Pavilhão Mourisco consta "Luiz Moraes Jr.", grafia que adotamos neste artigo. A leitura de seu currículo revela sua autoria como encarregado dos projetos e das obras de "grandes hospitais, do Instituto de Biologia e Bacteriologia 'Oswaldo Cruz', da Escola de Medicina e de outros serviços públicos". O próprio arquiteto destaca sua participação na Exposição Internacional de Higiene em Berlim, 1907, na qual recebeu um "grande diploma", e, também, na de Dresden, em 1911, e nas do Rio de Janeiro, em 1908 e 1909, nas quais receberia medalhas de ouro.

De fato, o universo de referências de Moraes Jr. é desconhecido, como Fonseca Filho argumenta. No entanto, não deve ser desprezível a influência em profissionais de repertório apreendido em catálogos, revistas, manuais, cartões-postais. Muitos arquitetos ecléticos eram autodidatas (Fabris, 1987).

Grafias e datas à parte, a procedência do arquiteto Luiz Moraes Jr. pode ser um indício de sua familiaridade com o estilo mourisco, mesmo que, para Olímpio da Fonseca, isso seja "fantasioso". O território que corresponde atualmente a Faro (ou Harun, em árabe) foi conquistado dos romanos e visigodos por povos mouros em 713. Permaneceu sob essa dominação durante mais de cinco séculos, até a reconquista dos territórios pelo rei dom Afonso III em 1249. Destaca-se que até 1910 a região era conhecida como um segundo reino português. O nome "Algarve", aliás, significa em árabe "o ocidente de Alandalus". Isso remonta à época que a região era um califado do Império Mouro na península Ibérica, um dos últimos territórios que resistiram à dominação portuguesa. A cidade era protegida por uma fortificação e murada romana que foi ampliada no período mulçumano e reconstruída, já sob dominação lusa. Destaca-se como remanescente dessa arquitetura militar moura o conjunto de duas torres da antiga muralha, denominado de torres albarrã (al-barran, em árabe) e popularmente conhecidas como "Arco do Repouso".

Se a ocupação moura deixou registros no imaginário nacional (lendas e mitos), por outro lado, quase não deixou marcas físicas expressivas na cidade - talvez pelo empenho português em remover as feições mouras ou pela destruição causada por guerras e no terremoto de 1755, que teve como consequência a perda de grande parte da muralha original da ocupação moura. Entretanto, reconhece-se, na cidade, alguns edifícios influenciados pela herança moura, revelando uma leitura neomourisca.

\section{Um castelo em Manguinhos}

A presença do orientalismo nas Américas, que se deu entre meados do século XIX e início do século XX, acompanhou a formação de uma nova cultura europeia em busca de 
se aproximar da estética formada pelo Oriente, norte da África e também sul da Espanha, representada pelo pitoresco e pelo sublime, "conjuntamente com os desejos da investigação científica e, como não, de um certo expansionismo econômico e político. Assistimos, portanto, ao momento orientalista do romantismo que se traduz em literatura, pintura e livros de viagem que estão na origem dessa estética árabe" (Guzman, Viñuales, 2016, p.13). Um componente primordial para essa aproximação se daria, sobretudo, pela arquitetura, sendo o edifício-sede da Fiocruz um perfeito exemplo disso no Brasil e na América Latina. O gosto pelo pitoresco, pelo raro e pelo sublime foi fundamental para arquiteturas que romperiam com a monotonia das edificações utilitárias da cidade industrial (Guzman, Viñuales, 2016). Seria recorrente a identificação dessa arquitetura como "mourisca" ou "neomourisca", coerente com a expressão anglo-saxã moorish style. A publicação em 1832 dos Contos de Alhambra e suas consequentes edições e traduções, do qual a Biblioteca de Obras Raras da Fiocruz tem um exemplar da edição de 1906, daria início a uma apropriação dessa estética, primeiramente na Inglaterra e depois nos EUA, chegando a demais países americanos, incluindo o Brasil.

O estilo árabe do castelo seria mesclado às referências inglesas e portuguesas, compostas harmoniosamente também em outros prédios que hoje constituem o Núcleo Arquitetônico Histórico de Manguinhos (Nahm), composição que não o desfavorece, mas, ao contrário, torna-o precioso e singular.

O Pavilhão Mourisco, a principal edificação desse conjunto, foi concebido a partir de um desenho do próprio Oswaldo Cruz. Nas mãos do arquiteto, essa versão original se corporificou em um projeto de estilo mourisco. Imaginando como seria a sede de seu novo instituto, Oswaldo Cruz teria desenhado no primeiro croqui para Moraes Jr., segundo Henrique Aragão, uma edificação em estilo bizantino. Depois, segundo ainda Aragão (1950, p.34), "ao tratar do assunto com Luiz Moraes, suas preferências encaminharam-se para o estilo mourisco, mais grandioso e mais fortemente evocador de mistérios como convinha à sede de uma instituição destinada a simbolizar a grandeza da ciência e a perscrutar os segredos da vida".

Acreditamos que houve três grandes influências na construção do Castelo da Fiocruz: o Observatório de Montsouris, em Paris (França), construído para a Exposição Universal de 1867 e de autoria de Louis-Étienne Alfred Chapon; o Palácio dos Leões em Alhambra, em Granada (Espanha), listado pela Unesco; e a Nova Sinagoga de Berlim (Alemanha), construída entre 1859 e 1866, de autoria de Eduard Knoblauch. Acompanhar a evolução dos projetos realizados para o Castelo de Manguinhos revela a influência que tais edificações tiveram na configuração final do Pavilhão Mourisco.

Segundo o museólogo Luiz Fernando Ribeiro, na justificativa de tombamento do Conjunto Arquitetural de Manguinhos, o primeiro esboço, feito pelo próprio cientista, imaginou uma "construção de corpo horizontal, com dois bastiões laterais, um central, dezessete janelas e uma grande porta com escada de acesso ao segundo andar. Apresentada a ideia ao arquiteto, este executa um trabalho semelhante ao de Oswaldo Cruz, sem as torres laterais, mas já em estilo mourisco" (Ribeiro, 1980, p.B). Essa configuração (Figura 1), sem as torres, tem grande semelhança com o Observatório de Montsouris (Figura 2). 
O observatório parisiense teria sido visitado algumas vezes por Oswaldo Cruz, durante sua estada no Instituto Pasteur (1898-1899), o que o qualifica como a primeira grande inspiração ao projeto de Moraes Jr.

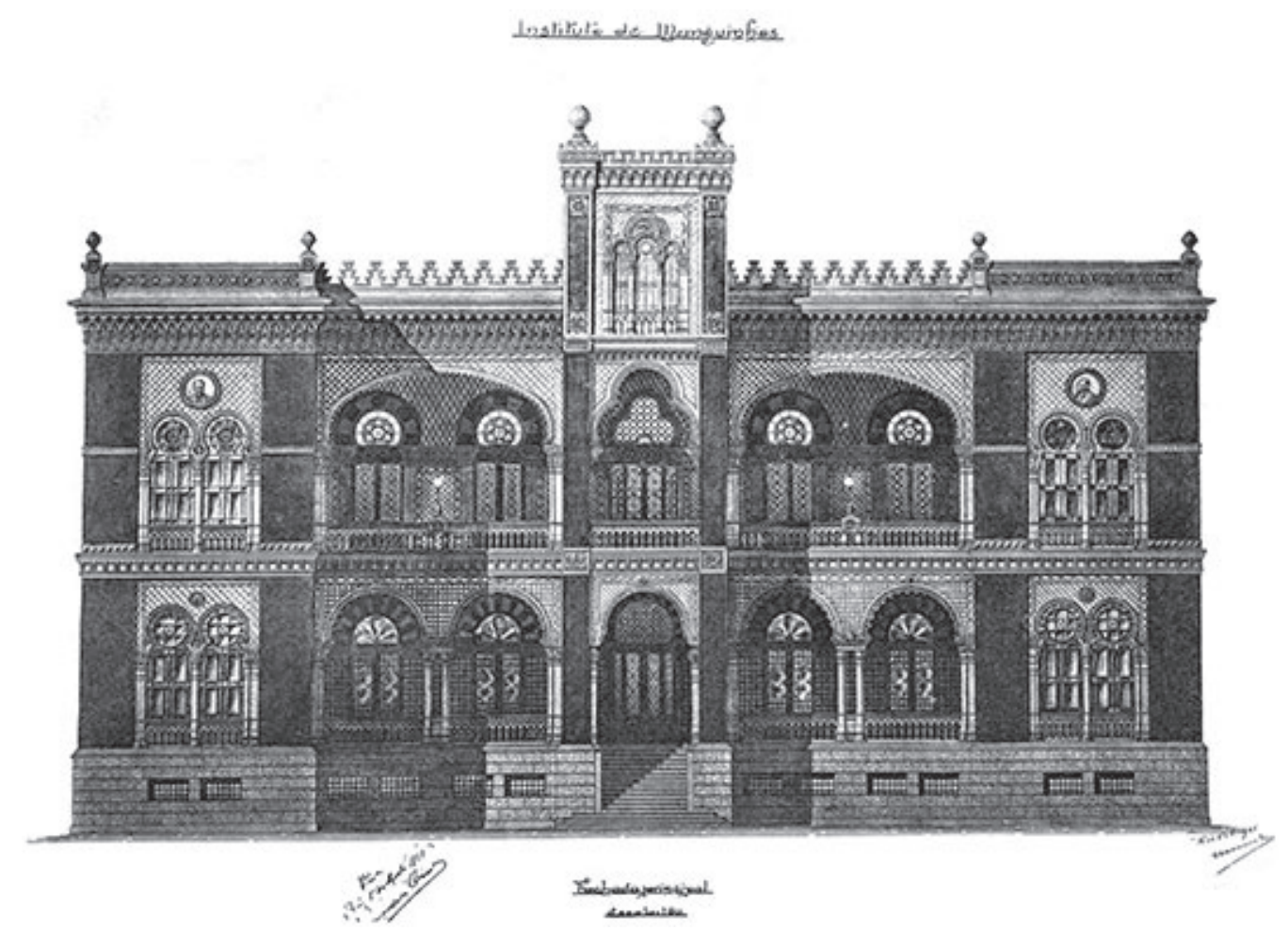

Figura 1: Primeiro projeto de Luiz Moraes Jr. para a sede do Instituto Oswaldo Cruz, 1905 (Acervo DAD/Fiocruz)

A influência do Observatório de Montsouris em Oswaldo Cruz é citada por alguns autores, mas ainda não foi devidamente explorada. Acreditamos que a edificação deve ser analisada mais detalhadamente, por suas semelhanças formais e a importância do monumento no contexto da produção arquitetônica francesa que apropria a corrente do orientalismo.

A edificação ficou conhecida por abrigar as instalações do Observatório de Paris a partir de 1868, mas, antes disso, foi projetada pelo arquiteto francês Louis-Étienne Alfred Chapon (1834-1893) para integrar o pavilhão da Tunísia, o "Palais du Bardo", durante a Exposição Universal de 1867, em Paris. Ao término da exposição, o pavilhão do observatório foi adquirido pela cidade de Paris, em 1868, e o monumento foi reconstruído em 1869 pelo arquiteto Gabriel Davioud em uma colina do Parc Montsouris. ${ }^{4}$

O pavilhão Palais du Bardo, por sua vez, foi inspirado em uma edificação palaciana de Túnis, na Tunísia, África do Norte. O projeto de Chapon era composto por três pavimentos e coroado por três cúpulas. Apesar de utilizar na fachada elementos replicados de seu exemplar original, o tratamento conferido no revestimento das fachadas é mais exuberante em detalhes e texturas, utilizando o repertório oriental de influência árabe e turca. 
A produção arquitetônica francesa do século XIX foi influenciada pela produção colonial na costa africana. Segundo Toulier (2006), o orientalismo aplicado na produção francesa pode ser separado em três momentos: primeiras grandes manifestações (1850-1870), apropriação em larga escala pela arquitetura recreativa, residencial e religiosa (1870-1914) e últimas manifestações no entreguerras (1914-1937).

Planejadores e arquitetos da École des Beaux-Arts atuaram ativamente nas colônias francesas, fosse em projetos de edifícios, fosse em urbanismo. A ênfase ao orientalismo - expresso em estilos descritos como "árabe", "mourisco" ou "hispano-mourisco' - era grande, sobretudo na arquitetura voltada para o divertimento e sem compromisso com uma fidelidade (Toulier, 2006). O estilo arquitetônico mourisco, peculiar às funções lúdicas, utiliza elementos estruturantes ou decorativos derivados do repertório de formas da tradição arquitetônica islâmica.

Nesse contexto, o Palais du Bardo corresponde ao primeiro surto de orientalismo em solo francês. Segundo Toulier (2006, p.8): “Uma cópia do palácio do Bei em Túnis, o Bardo, foi projetada por Alfred Chapon, arquiteto da Compagnie de Suez. Esta reconstrução toca a imaginação dos parisienses". Toulier (2006) afirma que o monumento permaneceu, por muito tempo, como referência imaginária de orientalismo para os franceses. Contudo, as palavras críticas do arquiteto francês Louis-Charles Boileau (1837-1914) expressam a liberdade criativa que movia as composições do orientalismo pelos integrantes da École des Beaux-Arts, sem uma rigidez tipológica.

Colocamos todos esses estilos no mesmo saco. Pouco nos importa a arte árabe da Belle Époque, Cairo ou Alexandria, a arquitetura mourisca da Espanha, a particular e interessante nuança da Pérsia, a decadência turca ou o estilo composto de Mahometan India; todas essas manifestações artísticas, no entanto, tão diversas, fundem-se para nós em um conjunto de fadas, das quais surgem formas singulares aqui e ali (Boileau citado em Toulier, 2006, p.1).

O palacete foi implantado em cima de uma colina do parque urbano de Montsouris, cercado por um extenso relvado. Pelas fotografias e gravuras (cartões-postais) pesquisadas, essa posição estratégica conferia imponência à edificação. O Parc Montsouris foi situado na periferia urbana da cidade de Paris, com traçado romântico, usual na época. A implantação desse parque foi uma das iniciativas de embelezamento urbano da administração de Haussmann, sob a régia de Luís Napoleão (Napoleão III), anteriormente comentadas. Oswaldo Cruz, durante sua estada em Paris com sua família, registrou algumas imagens de seus passeios aos parques da cidade. Os parques públicos, criados no século XIX, eram uma alternativa de lazer típica da época e configuravam-se como locais contemplativos, salubres e símbolos de status social. Levantamos a hipótese de que a implantação do Palais du Bardo, em relação ao Parc Montsouris (Figura 3), adequar-se-ia muito bem à intenção de posicionar o edifício-sede de sua própria instituição no terreno de Manguinhos, situado às margens da baía de Guanabara. 


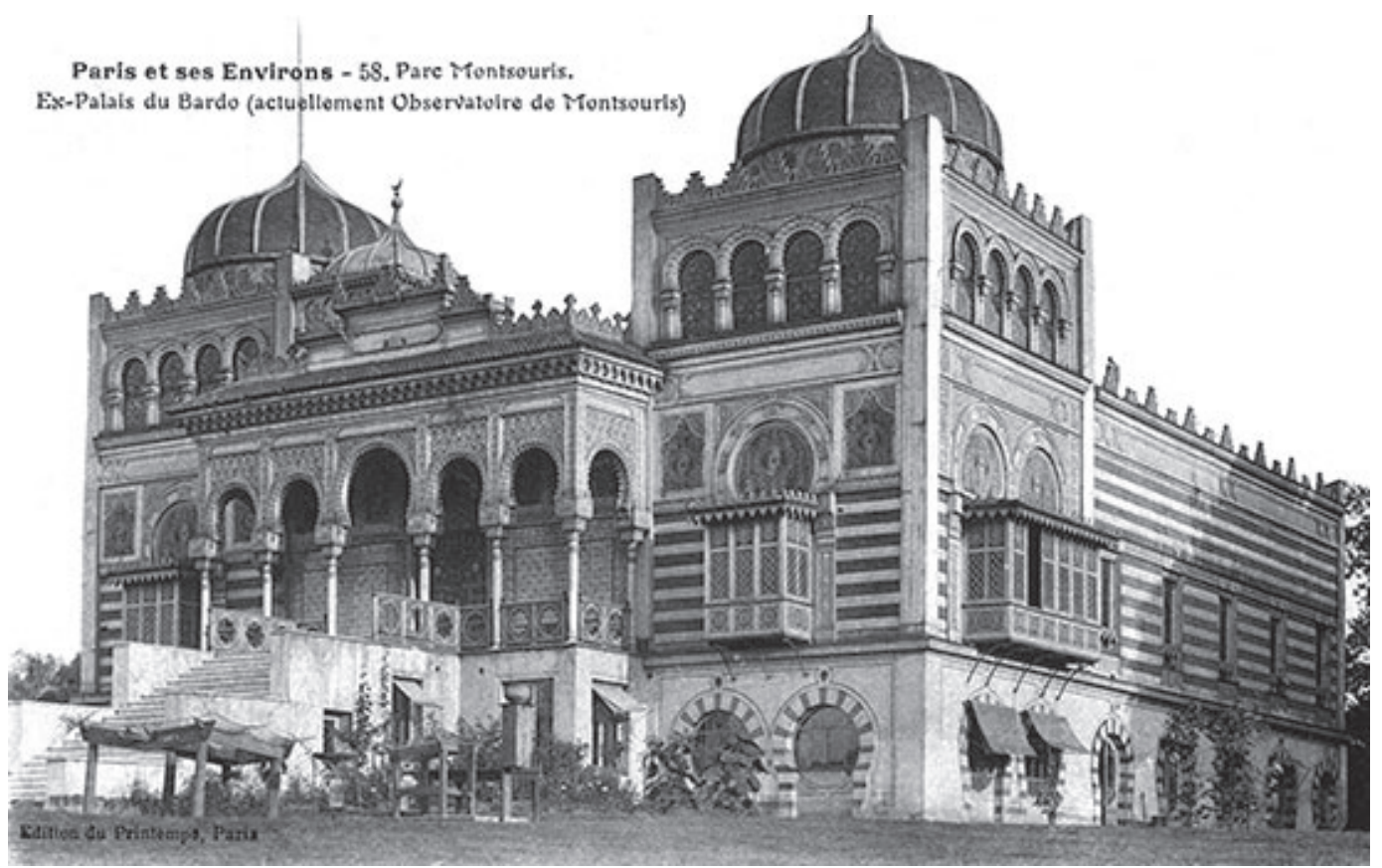

Figura 2: Observatório de Montsouris, antigo Palais du Bardo (acervo particular)

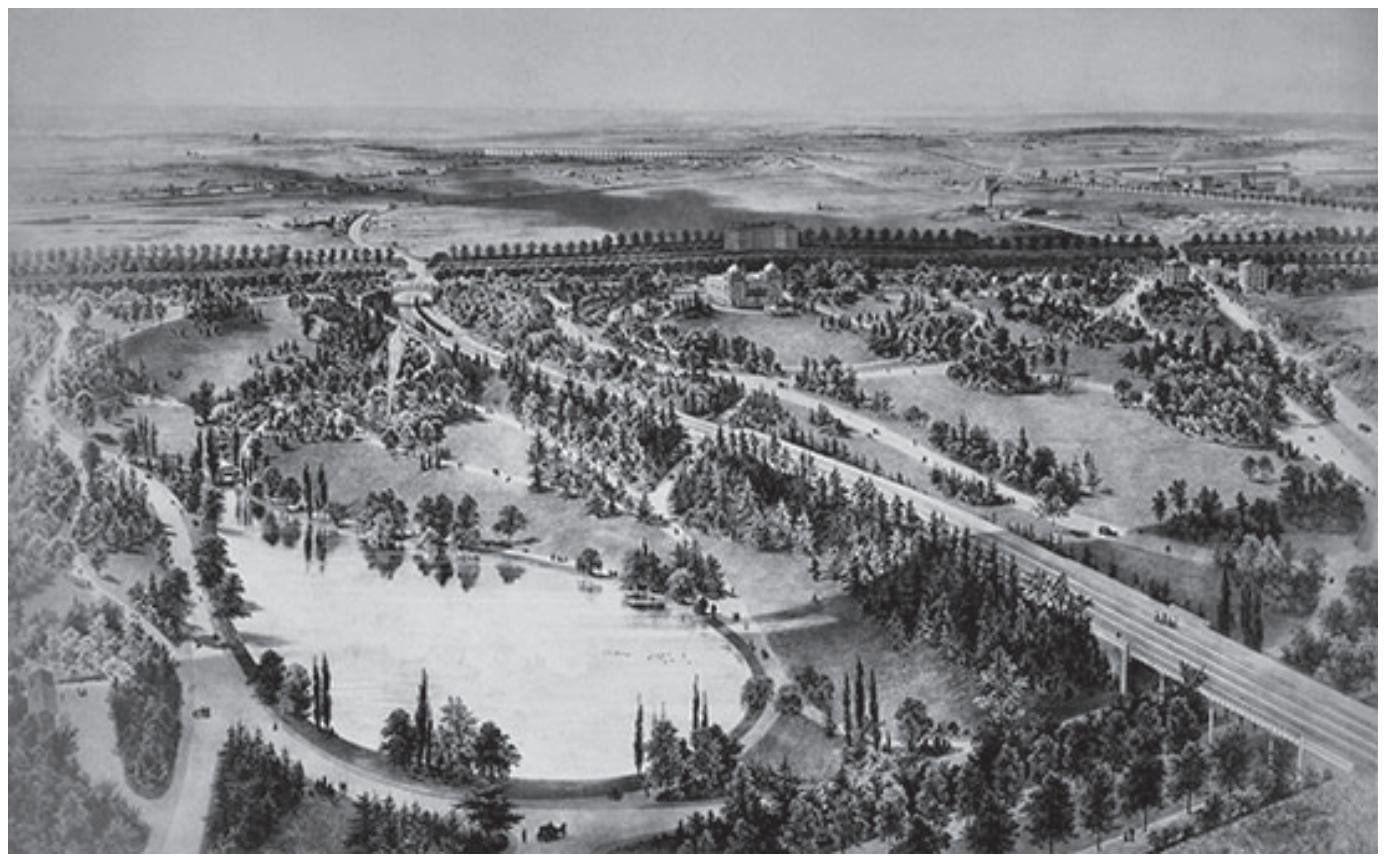

Figura 3: Parc Montsouris, cerca de 1853-1870 (State Library of Victoria)

Retomando o trabalho do museólogo Luiz Fernando, que examina as influências e o processo criativo da composição do Pavilhão Mourisco, "segue-se a esse projeto, um outro, no qual foram inseridas as duas torres", conforme observamos no postal encontrado no Fundo 
Luiz de Moraes Jr. e, até então, inédito (Figura 4). "O definitivo difere dos anteriores por possuir cinco andares, que conferem ao prédio não só mais espaço útil como, também, maior grandiosidade", conclui o museólogo (Ribeiro, 1980, p.B). Nesse caso (Figura 5), a configuração final do projeto, de 1908, com cinco pavimentos, teria sido apresentada após viagens do cientista e do arquiteto à Alemanha, quando tiveram contato com a Nova Sinagoga de Berlim.

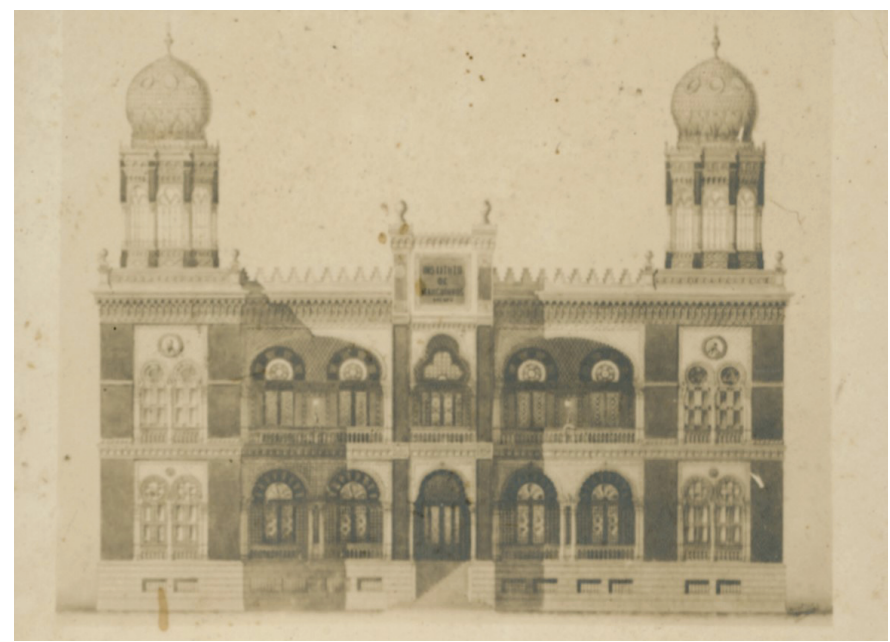

Figura 4: Postal de época apresentando o projeto em dois pavimentos e com as duas torres, etapa intermediária entre o projeto de 1905 e o de 1908 (acervo DAD/Fiocruz)

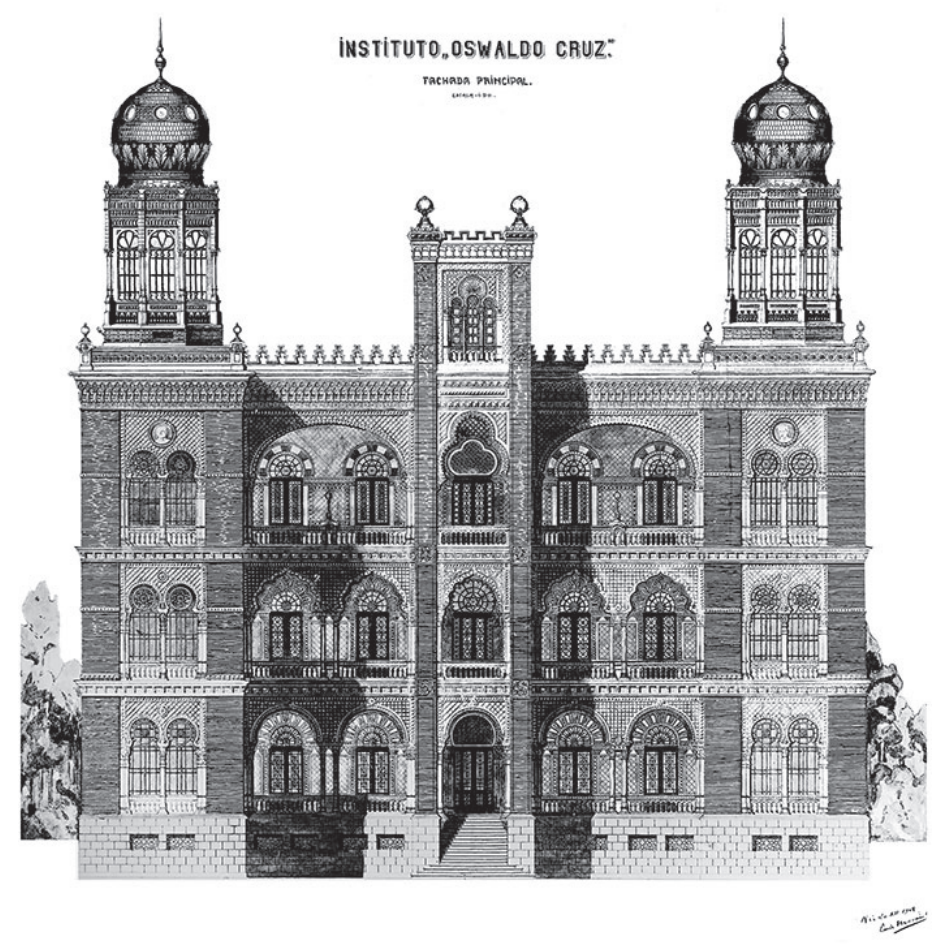

Figura 5: Projeto definitivo do Pavilhão Mourisco; autoria de Luiz Moraes Jr., 1908 (acervo DAD/Fiocruz) 
Oswaldo Cruz esteve duas vezes na Alemanha na companhia de Moraes Jr. para participar das Exposições Internacionais de Higiene - em 1907, em Berlim -, ocasião em que o instituto receberia a Medalha de Ouro; e em 1911, em Dresden (Figura 6): "Na maquete exibida na Exposição de Higiene de Berlim, em 1907, o edifício já se apresentava com as duas torres. Mas só em 1908, com a construção em estágio bem adiantado, Moraes confeccionou o projeto definitivo em cinco pavimentos" (Benchimol, 1990, p.110). Certamente, na primeira viagem, ambos teriam tido contato com a Sinagoga de Berlim e se inspirado para concluir o projeto do edifício principal.

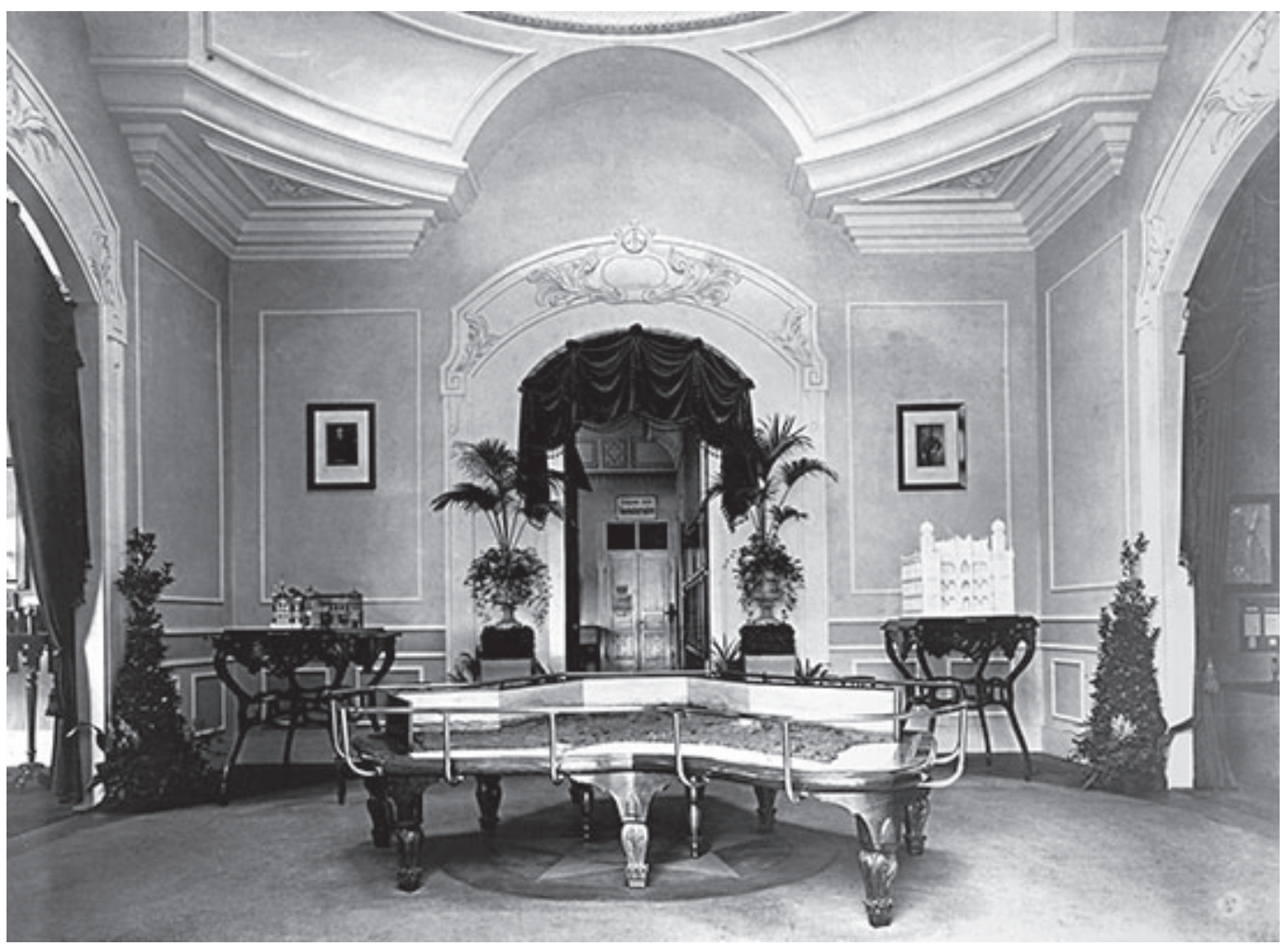

Figura 6: Foto da exposição de Dresden (1911); à direita, a maquete da antiga Diretoria-geral de Saúde Pública, então com dois pavimentos, localizada na rua do Resende, Centro do Rio; à esquerda, a maquete com a configuração definitiva do Castelo de Manguinhos (acervo DAD/Fiocruz)

A referência à Sinagoga de Berlim deu a configuração final ao projeto do Castelo Mourisco da Fiocruz como o conhecemos até hoje, ao menos em sua fachada principal. A sinagoga está alinhada a outros edifícios situados ao seu redor, diferente do Castelo Mourisco da Fiocruz, posicionado em meio de terreno, com as quatro fachadas visíveis, semelhante implantação do Palácio de Montsouris em seu parque. Portanto, apenas a fachada anterior da sinagoga se apresenta à cidade. Pela análise dessa fachada, vemos o quanto sua imponência acabou por influenciar o projeto final para Manguinhos. A sinagoga apresenta um pavimento térreo e três pavimentos superiores, além de elementos visuais, como arcos, cornijas e platibandas ao longo de todo o pano da fachada. $\mathrm{Na}$ 
horizontalidade, essa se divide em três subplanos, o central e os dois laterais. No ápice dos planos laterais se localizam as torres octogonais. Todos esses detalhes e opções de estilo podem ser vistos no palácio do Rio de Janeiro. As semelhanças são, de fato, incríveis para ser descartadas como mera coincidência (Figura 7).

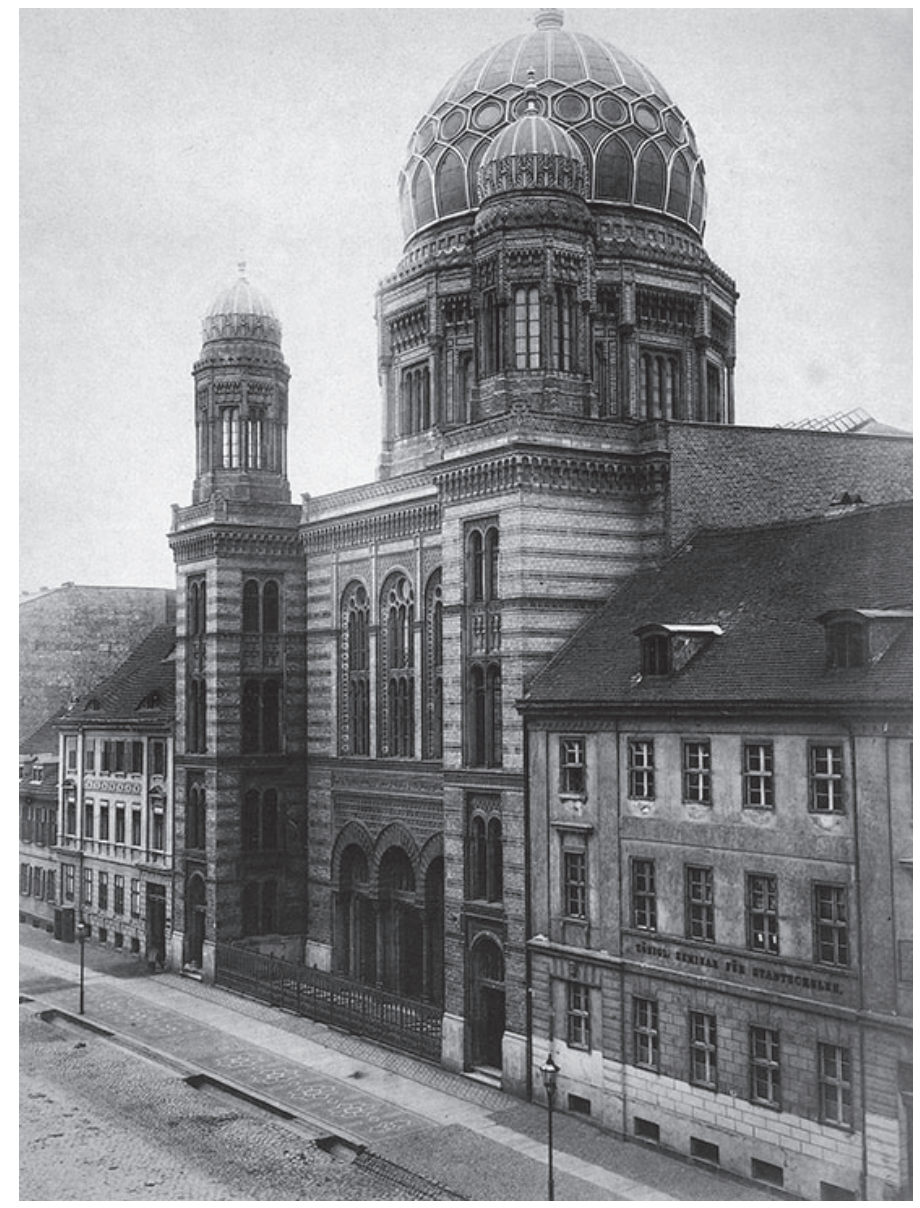

Figura 7: Nova Sinagoga de Berlim (Berlin State Archives)

Na parte decorativa, com certeza, a grande referência ficaria por conta do Palácio de Alhambra, em Granada. O livro sobre Alhambra, editado em 1906 por Albert F. Calvert, oriundo da biblioteca particular de Oswaldo Cruz e hoje pertencente ao acervo da Biblioteca de Obras Raras da Fiocruz, traz desenhos adotados por Moraes Jr. em Manguinhos. O livro transcreve os estudos de Owen Jones sobre as experiências decorativas mouras de Granada, primeiramente publicadas em 1837, em Londres, sob o título Plans, elevations, sections and details of the Alhambra, de Jules Goury e Owen Jones. A burguesia europeia do século XIX adotaria a linguagem neoárabe com "conotações de evasão, evocação e singularidade social muito importantes, adotando os palácios de Alhambra como principal modelo referencial que suscitara - sempre por meio da decoração - um amplo repertório emocional" (Domingo, 1998, p.115). 
Em relação à realização de uma arquitetura pensada para uma instituição de saúde, Moraes Jr. escolhe uma configuração em que uma planta simétrica se apresenta dividida em um corpo central, onde se localizam os acessos (escadas, elevadores e halls de distribuição) e os banheiros; e duas alas, nas quais se distribuem as salas de laboratório, as estantes da biblioteca e os terraços, constituindo um " $\mathrm{H}$ ". Contornando essas alas e, também, na parte frontal da edificação, localizam-se as "varandas de aeração" (Ribeiro, 1980, p.B). Essa característica implantação em " $\mathrm{H}$ " está muito associada às edificações de saúde, como as do próprio Instituto Pasteur, de Paris, por permitir, justamente, a ventilação cruzada, ou a aeração, mencionada por Luiz Fernando Ribeiro, e a insolação para o interior das salas, medidas tidas como higiênicas e grandemente utilizadas à época como recurso de projeto.

Fora isso, pequenos detalhes construtivos e no uso dos materiais revelam a real demanda para o programa de necessidades do edifício-sede da Fiocruz, alguns relatados por Oswaldo Cruz em sua visita a Garches, como vimos: cantos arredondados no encontro das paredes e delas com os pisos e os tetos, que evitam acúmulo de sujeiras - grandemente utilizado até hoje em laboratórios de biotecnologia -; o uso de azulejos brancos no interior das salas e nos corredores de acesso a elas, que facilita a limpeza; grandes vãos de janela, que permitem a troca do ar; instalações a gás, usadas para alimentar as experiências praticadas ainda hoje nos laboratórios do segundo piso; anfiteatro, para as aulas teóricas do Curso de Aplicação, do então Instituto Oswaldo Cruz; o uso de claraboias, para permitir a entrada de luz solar na edificação; a localização dos banheiros em uma estrutura independente, para efeitos de higiene, mas interligada ao bloco central por meio de uma passarela coberta, entre outros recursos.

Por essas e outras características, o edifício-central da Fiocruz, juntamente com outros componentes do Nahm, foi tombado em 1981, sendo uma das missões da Fundação Oswaldo Cruz preservá-lo para as futuras gerações. Esse reconhecimento só ocorreu nos anos 1980, devido a entendimentos por parte dos órgãos de tombamento de que essa arquitetura não era considerada genuinamente brasileira. O arquiteto italiano Luciano Pateta (1987) afirma que foi a perda progressiva dos preconceitos críticos que levou a historiografia arquitetônica, no âmbito europeu, a reavaliar, no final do século XX, o ecletismo. Isso também foi válido no Brasil.

Ressalta-se a contribuição da Carta de Veneza (1964) e suas repercussões no Brasil na década seguinte para a valorização da história urbana em consonância à moderna teoria de preservação. Foi na década de 1970 que essa perspectiva dos atributos da arquitetura eclética começou a ser modificada, principalmente a partir da descentralização do patrimônio, com a criação de institutos estaduais de preservação.

\section{Considerações finais}

À luz de uma nova historiografia da arquitetura brasileira, o ecletismo foi objeto de estudos e pesquisas pioneiros durante as décadas de 1970 e 1980 por arquitetos e historiadores da arte, tais como Mário Barata, Paulo Santos e Giovanna Del Brenna. Eles iniciaram o reconhecimento do ecletismo sob o prisma da importância didática para a história da arte. Apesar de partirem de perspectivas distintas, acabaram por reforçar pontos 
comuns associados ao estilo: a importância da industrialização e o desenvolvimento da cultura urbana. Seus trabalhos contribuíram para reivindicar, a partir da metade da década de 1980, o espaço da arquitetura eclética na historiografia da arquitetura carioca.

Defendia-se, portanto, tombar conjuntos de edifícios pelo fato de se constituírem testemunho vivo da remodelação da cidade. Assim, o ecletismo passava a ser compreendido como mais um dos fenômenos artísticos no contexto da civilização urbana. Bens arquitetônicos que não se enquadravam aos fatos memoráveis de excepcional valor puderam, a partir de então, ser reavaliados.

Em 1977, Paulo Santos publicou o seu livro Quatro séculos de arquitetura, no qual teceu com extrema sensibilidade a história da arquitetura brasileira ao longo de quatrocentos anos, não omitindo a arquitetura eclética. No capítulo que dedica às manifestações ecléticas de corrente neogótica e dos estilos orientais, faz referência ao Pavilhão Mourisco e à sua paisagem circundante:

No Instituto de Manguinhos, obra do arquiteto Moraes Júnior (também autor do edifício da Beneficência Portuguesa e da Igreja da Penha), que, com sua graciosa silhueta de tons rosados emergindo dos altos de um outeiro, forma hoje agradável contraste para quem vem da Ilha do Fundão com as formas funcionalmente frias da Universidade do Brasil (Santos, 1977, p.88).

A valorização da arquitetura eclética resultaria em atos de preservação, efetivados na década seguinte, em sua maioria, a partir de iniciativas pioneiras das instituições de proteção, como o Instituto do Patrimônio Artístico e Nacional (Iphan). Dos anos 1970 em diante ocorreria um aumento significativo de pedidos de tombamentos, desta vez, por solicitação externa à instituição. As solicitações partiam de governos locais e da direção das próprias instituições - como foi o caso da Fiocruz.

O pedido de tombamento federal do "Conjunto Arquitetural de Manguinhos" foi feito pelo presidente da instituição, Guilardo Martins Alves, em correspondência (Ofício..., 8 set. 1980) de setembro de 1980. Para subsidiar o pedido de abertura de processo de tombamento foi preparado, por Luiz Fernando Ribeiro, museólogo da Fiocruz, um estudo detalhado do "Conjunto Arquitetural de Manguinhos", ressaltando suas qualidades arquitetônicas e seu significado para a história da cidade do Rio de Janeiro no contexto da implantação da República brasileira.

A história de seu projeto, da qual tentamos aqui elucidar as principais referências, de Montsouris a Garches, de Alhambra a Berlim, contribui para se entender a maneira como o próprio estilo eclético se apresenta, constitui-se e é valorizado hoje. A preservação do edifício principal da atual Fundação Oswaldo Cruz, em mais de três décadas de compromisso institucional, mantém viva a responsabilidade de salvaguardar um patrimônio cultural das ciências e da saúde, que ainda guarda seus mistérios e encantamentos.

\section{NOTAS}

${ }^{1}$ Nessa e nas demais citações de textos em outros idiomas, a tradução é livre.

${ }^{2}$ Para mais informações ver Rocha-Peixoto (2001); Pereira (jul. 2007); e Kaufmann (1952). 
${ }^{3} \mathrm{O}$ crescimento da capital francesa exigia desobstruções, abertura de novas ruas e o estabelecimento de esgotos que resultariam na aliança entre os princípios da higiene e os da estética, um novo cenário para a cidade após anos de cólera e tifo.

${ }^{4}$ O palacete foi abandonado a partir de 1974. Em 1991, o governo da Tunísia pretendia adquiri-lo, por um preço simbólico, para reconstruí-lo em seu território, mas, nesse mesmo ano, um incêndio destruiu por completo a edificação.

\section{REFERÊNCIAS}

ABREU, Maurício de.

A evolução urbana do Rio de Janeiro. Rio de Janeiro: IplanRio; Zahar. 1987.

ARAGÃO, Henrique.

Notícia histórica sobre a fundação do Instituto Oswaldo Cruz. Rio de Janeiro: Serviço Gráfico do Instituto Brasileiro de Geografia e Estatística. 1950.

BARBUY, Heloisa.

O Brasil vai a Paris em 1889: um lugar na Exposição Universal. Anais do Museu Paulista, v.4, p.211-261. 1996.

BENCHIMOL, Jaime Larry.

Pereira Passos: um Haussmann tropical. Rio de Janeiro: Secretaria Municipal de Cultura, Turismo e Esportes; Departamento Geral de Documentação e Informação Cultural. 1992.

BENCHIMOL, Jaime (Org.).

Manguinhos do sonho à vida: a ciência na belle époque. Rio de Janeiro: Casa de Oswaldo Cruz. 1990.

CALABI, Donatella.

História do urbanismo europeu: questões, instrumento, casos exemplares. São Paulo: Perspectiva. 2012.

COSTA, Renato da Gama-Rosa.

100 anos do Castelo da Fiocruz: criador e criatura. Brasiliana Fotográfica. Disponível em: <http://brasilianafotografica.bn.br/?p=11758>. Acesso em: 12 jul. 2019. 15 maio 2018.

CRUZ, Oswaldo.

Opera Omnia. Rio de Janeiro: Instituto de Medicina Experimental. 1972.

DOMINGO, José Manuel Rodriguez.

La Alhambra de Oriente: la restauracion del patrimônio monumental hispanomusulmán y el medievalismo islámico. Coloquio Internacional de Historia del Arte. Ciudad de México: Universidad Nacional Autónoma de México. 1998.

FABRIS, Annateresa.

Arquitetura eclética no Brasil: o cenário da modernização. In: Fabris, Annateresa (Org.). Ecletismo na arquitetura brasileira. São Paulo: Nobel; Editora da Universidade de São Paulo. p.131-307. 1987.
GUZMÁN, Rafael López; VIÑUALES, Rodrigo

Gutierrez (Coord.).

Alhambras: arquitetctura neo-árabe em

Latinoamérica. Granada: ETC Ediciones. 2016.

FONSECA FILHO, Olympio da.

Oswaldo Cruz Monumenta Historica, t.2:

Escola de Manguinhos. In: Coura, José

Rodrigues; Ferreira, Luiz Fernando; Paraense,

Wladimir Lobato (Org.). Centenário do Instituto Oswaldo Cruz: 1900-2000. Rio de Janeiro:

Memórias do Instituto Oswaldo Cruz. p.95-220. 2000.

KAUFMANN, Emil.

Three revolutionary architects, Boullee, Ledoux, and Lequeu. Philadelphia: The American Philosophical Society. 1952.

KLEIN, Lisabel (Org.).

Oswaldo Cruz: o médico do Brasil. Salvador: Fundação Odebrecht; Brasília: Fundação Banco do Brasil. 2003.

LIVRO...

Livro de Batismos do ano de 1867. Faro: Paróquia de São Pedro. 1867.

MIGNOT, Claude.

Architecture of the 19th Century. Fribourg: Office Du Livre. 1983.

OFÍCIO...

Ofício n.462/80-PR/Fiocruz. Rio de Janeiro: DPH/COC/Fiocruz. 8 set. 1980.

PATETA, Luciano.

Considerações sobre o ecletismo na Europa. In: Fabris, Annateresa (Org.). Ecletismo na arquitetura brasileira. São Paulo: Nobel; Editora da Universidade de São Paulo. p.8-27. 1987.

PEREIRA, Margareth da Silva.

A exposição de 1908 ou o Brasil visto por dentro. Arqtexto, n.16, p.6-27. 2013.

PEREIRA, Sonia Gomes.

A historiografia da arquitetura brasileira no século XIX e os conceitos de estilo e tipologia. 19\&20, v.2, n.3. Disponível em: <http://www. dezenovevinte.net/arte\%20decorativa/ad_sgp. htm>. Acesso em: 30 dez. 2019. jul. 2007. 
PINHEIRO, Eloísa Petti.

Europa, França e Bahia: difusão e adaptação de modelos urbanos. Salvador: Edufba. 2002.

RIBEIRO, Luiz Fernando Fernandes.

Conjunto Arquitetural de Manguinhos. In: Brasil. Proc. n.1.037-T-80. Pedido de tombamento: Instituto Oswaldo Cruz (Manguinhos). Mimeo. Rio de Janeiro. 1980.

ROCHA-PEIXOTO, Gustavo.

O ecletismo e seus contemporâneos na arquitetura do Rio de Janeiro. In: Rocha-Peixoto, Gustavo; Czajkowski, Jorge (Org.). Guia da arquitetura eclética no Rio de Janeiro. v.1. Rio de Janeiro: Casa da Palavra; Prefeitura da Cidade do Rio de Janeiro. p.5-24. 2001.

SANTOS, Paulo.

Quatro séculos de arquitetura. Valença: Editora Valença S.A. 1977.
SEVCENKO, Nicolau.

Introdução. In: Novais, Fernando A.; Sevcenko, Nicolau (Org.). História da vida privada no Brasil. v.3. São Paulo: Companhia das Letras. p.7-48. 1998.

TOULIER, Bernard.

Un parfum d'Orient au cour des villes d'eaux. In Situ: Revue des patrimoines, n.7, p.1-26.

Disponível em: <http://journals.openedition. org/insitu/3069>. Acesso em: 1 jun. 2019. 2006.

VASSEUR, Édouard.

L'Exposition universelle de 1867: um évenement architectural à travers la presse spécialisée.

Livraisons d'histoire de l'architecture, n.2, p.71-88. 2001. 